\title{
Chemokine-Like Receptor 1
}

National Cancer Institute

\section{Source}

National Cancer Institute. Chemokine-Like Receptor 1. NCI Thesaurus. Code C25985.

Chemokine-like receptor 1 (373 aa, $\sim 42 \mathrm{kDa}$ ) is encoded by the human CMKLR1 gene.

This protein plays a role in chemoattraction, adipogenesis, angiogenesis, and bone development. 